\title{
Penggunaan Cocopeat Sebagai Pengganti Topsoil Dalam Upaya Perbaikan Kualitas Lingkungan di Lahan Pascatambang di Desa Toba, Kabupaten Sanggau.
}

\author{
Wafa Shafira, Aji Ali Akbar, Ochih Saziati* \\ Jurusan Teknik Lingkungan, Universitas Tanjungpura, Pontianak, Indonesia
}

\begin{abstract}
ABSTRAK
PT. Dinamika Sejahtera Mandiri (PT. DSM) merupakan perusahaan swasta yang bergerak di bidang pertambangan bauksit dengan sistem penambangan terbuka, sehingga menghasilkan hamparan tanah dengan kandungan bahan organik dan unsur hara sangat rendah serta toksik tinggi sehingga lahan menjadi kritis. Upaya perbaikan lingkungan dilakukan dengan rehabilitasi lahan agar tidak menimbulkan kerusakan berkelanjutan. PT. DSM menggunakan penambahan biostimulan dalam rehabilitasi lahan, namun karena biaya yang mahal maka dilakukan alternatif menggunakan cocopeat sebagai pengganti topsoil dengan biaya terjangkau. Lokasi penelitian terletak di lahan pascatambang bauksit milik PT. DSM yang berada di Desa Teraju, Kecamatan Toba, Kabupaten Sanggau, Provinsi Kalimantan Barat. Total sampel tanah yang diuji sebanyak 23 sampel, terdiri dari 5 perlakuan dengan masing-masing perlakuan dilakukan pengulangan sebanyak 3 kali, yaitu perlakuan A tanpa perlakuan di lahan dengan topsoil, perlakuan B tanpa perlakuan di lahan tanpa topsoil, perlakuan C 100\% cocopeat, perlakuan D 50\% cocopeat $+25 \%$ arang sekam $+25 \%$ kotoran ayam dan perlakuan E $60 \%$ cocopeat $+25 \%$ arang sekam $+15 \%$ kotoran ayam. Hasil penelitian menunjukan kandungan parameter $\mathrm{pH}, \% \mathrm{C}$ - organik, KTK, dan $\mathrm{N}$ total dalam media tanam cocopeat memiliki kandungan yang lebih baik daripada topsoil dan tanah pascatambang, namun parameter $\mathrm{P}_{2} \mathrm{O}_{5}$, kadar debu, liat, dan pasir, topsoil memiliki kandungan yang lebih baik daripada cocopeat dan tanah pascatambang. Kandungan parameter fisik dan kimia terendah terdapat pada tanah pascatambang. Komposisi media tanam kombinasi cocopeat, arang sekam, dan kotoran ayam memiliki pengaruh yang baik terhadap pertumbuhan tanaman sengon karena memiliki unsur hara yang lebih baik dibandingkan dengan topsoil, tanpa topsoil atau hanya cocopeat saja. Dosis variasi paling optimal dalam pertumbuhan sengon dari segi pertumbuhan fisik tanaman yaitu pada variasi perlakuan kode tanam D, yaitu memiliki pertambahan tinggi tanaman rata-rata $13,7 \mathrm{~cm}$ dan cabang daun sebanyak 6 helai yang lebih signifikan dibandingkan perlakuan media tanam lainnya.
\end{abstract}

Kata kunci: Cocopeat, Rehabilitasi, Lahan Pascatambang

\section{ABSTRACT}

PT. Dinamika Sejahtera Mandiri (PT. DSM) is a private company engaged in bauxite mining with an open mining system, resulting in a stretch of land with very low organic and nutrient content and high toxicity so that the land becomes critical. Efforts to improve the environment are carried out by rehabilitating land so as not to cause sustainable damage. PT. DSM uses biostimulants in land rehabilitation, but an alternative is to use cocopeat as a substitute for topsoil at an affordable price because of the high cost. The research location is located on the bauxite post-mining land owned by PT. DSM is located in Teraju Village, Toba District, Sanggau Regency, West Kalimantan Province. Total soil samples tested were 23 samples, consisting of 5 treatments with each treatment being repeated three times, namely treatment A without treatment on land with topsoil, treatment B without treatment on the ground without topsoil, treatment C $100 \%$ cocopeat, treatment D 50\% cocopeat $+25 \%$ husk charcoal $+25 \%$ chicken manure and treatment $\mathrm{E} 60 \%$ cocopeat $+25 \%$ husk charcoal $+15 \%$ chicken manure. The results showed that the $\mathrm{pH}, \% \mathrm{C}$ - organic, $\mathrm{CEC}$, and total $\mathrm{N}$ content in the cocopeat growing medium had a better range than topsoil and post-mining soil. Still, the $\mathrm{P}_{2} \mathrm{O}_{5}$ parameters, the content of dust, clay, and sand, topsoil had better content. Then cocopeat and post-mining land. The lowest range of physical and chemical parameters is found in post-mining soil. The composition of the planting medium combination of cocopeat, husk charcoal, and chicken manure has a good effect on the growth of Sengon plants because it has better nutrients than topsoil, without topsoil, or just cocopeat. The most optimal dose of variation in the evolution of Sengon in terms of physical plant growth is the variation in the treatment of planting code $\mathrm{D}$, which has an average plant height increase of $13.7 \mathrm{~cm}$ and six-leaf branches, which is more significant than the treatment of other growing media.

Keywords: cocopeat, rehabilitation, post-mining bauxite,

Citation: Shafira,W., Akbar A.A., dan Saziati, O. (2021) Penggunaan Cocopeat Sebagai Pengganti Topsoil Dalam Upaya Perbaikan Kualitas Lingkungan di Lahan Pascatambang di Desa Toba, Kabupaten Sanggau. Jurnal Ilmu Lingkungan, 19(2), 432-443, doi:10.14710/jil.19.2.432-443

\section{Pendahuluan}

Bauksit merupakan salah satu mineral logam yang terdapat banyak di Kalimantan Barat. Berdasarkan laporan Izin Usaha Pertambangan (IUP), total produksi bauksit Kalimantan Barat hingga Agustus 2019 mencapai 11.608.937 metrik ton (MT). Salah satu

\footnotetext{
* Penulis korespondensi: ochisaziati@enviro.untan.ac.id
} 
perusahaan swasta yang bergerak dibidang pertambangan bauksit adalah PT. Dinamika Sejahtera Mandiri. Penambangan bauksit dilakukan dengan sistem penambangan terbuka yang menyebabkan lahan menjadi kritis. open pit mining atau penambangan terbuka dilakukan dengan mengambil tanah hingga kedalaman tertentu hingga didapatkan bahan mineralnya (Mulyanto, 2008 dalam Rachman dkk, 2007). Penambangan terbuka ini menyebabkan tanah topsoil dan bahan batuan atau over burden becampur sehingga tanah menjadi miskin hara dan bahan organik, toksik serta tidak berstruktur (Mulyanto, 2008 dalam Rachman dkk, 2017). Rendahnya kandungan nilai NPK (Nitrogen, Phospor, dan Kalium) pada bekas tambang bauksit merupakan salah satu penyebab lahan menjadi kritis (Sembiring, 2008). Kerusakan strukutr tanah ini mengakibatkan tanah sulit menyimpan air ketika terjadi hujan hal ini menyebabkan tingginya laju erosi, sedangkan ketika musim kemarau tanah akan menjadi sulit diolah karena padat dan keras (Sembiring, 2008).

Salah satu upaya perbaikan lingkungan yang dapat dilakukan yaitu rehabilitasi lahan agar tidak menimbulkan kerusakan berkelanjutan. Aktivitas rehabilitasi lahan kritis pascatambang pada prinsipnya antara lain harus bersifat konservatif (Munir, 2017). PT. Dinamika Sejahtera Mandiri telah melakukan reklamasi dengan menambahkan biostimulan untuk memperbaiki kualitas tanah tanpa topsoil, namun karena biaya yang mahal maka dilakukan penelitian menggunakan cocopeat sebagai pengganti topsoil untuk melihat alternatif dengan biaya terjangkau yang dapat dilakukan dalam proses reklamasi lahan pascatambang. Bentuk rehabilitasi lahan yang dilakukan adalah revegetasi. Tanaman yang akan digunakan dalam revegetasi yaitu sengon (Paraserianthes falcataria) tanaman ini bisa tumbuh di kondisi miskin hara dan air serta lahan yang ekstrim, maka tanaman ini dapat digunakan sebagai tanaman dalam rehabilitasi lahan kritis karena dapat meningkatkan kualitas tanah. (Setiadi, 2001 dalam Fitriani, 2016). Media tanam yang baik diperlukan dalam proses keberhasilan revegetasi lahan pascatambang bauksit.

Cocopeat adalah media tanam yang dibuat dari sabut kelapa sebagai pengganti tanah. Menurut Badan Pusat Statistik, produksi buah kelapa di Kalimantan Barat pada tahun 2019 mencapai 954.737 ton dan menghasilkan 124 ton sabut kelapa pertahunnya. Besarnya potensi sabut kelapa yang tidak sepenuhnya dimanfaatkan dalam produksi agar memiliki nilai ekonomis, menyebabkan terjadinya permasalahan lingkungan karna limbah. Cocopeat merupakan media tanam didapatkan dari proses penghancuran sabut kelapa, yang menghasilkan serat atau fiber, serta serbuk halus atau cocopeat (Irawan dan Hidayah, 2014). Cocopeat diharapkan dapat digunakan sebagai pengganti topsoil. Menurut Irawan dan Kafiar (2015) serta Agustin (2009), cocopeat memiliki kemampuan menyerap air dan menggemburkan tanah. Cocopeat lebih cocok digunakan untuk kegiatan rehabilitasi lahan kritis di daerah beriklim kering seperti lahan pascatambang bauksit di Desa Teraju.

Cocopeat mengandung unsur-unsur hara yang penting seperti, fosfor (P), kalium (K), magnesium (Mg), natrium (N), dan kalsium (Ca) (Agustin, 2009). Menurut penelitian Cahyo dkk (2019), cocopeat dapat digunakan sebagai pengganti top soil media tanam karet. Rasio terbaik dari cocopeat ke tanah untuk bahan tanam karet adalah 80:20 dengan 80 untuk cocopeat dan 20 untuk tanah. Pemanfaatan cocopeat sebagai media tanam harus diikuti dengan pemupukan berimbang untuk memberikan nutrisi yang tidak tersedia di cocopeat.

Campuran media tanam yang akan digunakan pada penelitian ini adalah cocopeat, arang sekam dan kotoran ayam. Arang sekam juga memiliki kandungan karbon (C) yang tinggi dan dapat meningkatkan porositas tanah sehingga membuat media tanam ini menjadi gembur. Menurut penelitian Margareta (2017) Pertumbuhan tinggi tanaman ciplukan dan jumlah helainya dipengaruhi oleh kombinasi tanah, arang sekam, kapur, dan pupuk kandang berpengaruh. Kotoran ayam mempunyai kadar unsur hara serta bahan organik yang tinggi dan rendah kadar air maka kotoran ayam dipilih sebagai pupu kandang yang digunakan.

Berdasarkan hasil penelitian dari beberapa peneliti, penggunaan pupuk kandang ayam memberikan respon yang baik terhadp tanaman pada musim pertama, karena cepatnya proses dekomposisi dari kotoran ayam serta tingginya unsur hara jika dibandingkan dengan jenis pupuk kandang yang lain dengan berat yang sama. Menurut Penelitian Ramadhani (2018), adanya pemberian cocopeat dan pupuk kandang kotoran ayam berpengaruh nyata terhadap helai daun bibit mahoni pertumbuhan tinggi, namun tidak memiliki pengaruh nyata terhadap pertumbuhan diameter. Berdasarkan uraian tersebut, maka dilakukan penelitian penggunan cocopeat sebagai pengganti topsoil serta salah satu media tanam di lahan pascatambang bauksit sebagai upaya perbaikan kualitas lingkungan yang bertujuan untuk mengidentifikasi kandungan parameter $\mathrm{pH}, \%$ organik, $\mathrm{KTK}, \mathrm{N}$ total $\mathrm{P}_{2} \mathrm{O}_{5}$ kadar debu, liat, dan pasir dalam media tanam cocopeat, topsoil dan tanah pascatambang, mengkaji pengaruh cocopeat, arang sekam dan kotoran ayam pada tanah sebagai media tumbuh tanaman pengganti topsoil di lahan pascatambang bauksit, mengidentifikasi pengaruh perlakuan media tanam campuran cocopeat, arang sekam, dan kotoran ayam sebagai media tumbuh tanaman pengganti topsoil di lahan pascatambang bauksit terhadap pertumbuhan tanaman sengon. Serta menganalisis pengaruh penggunan dosis media cocopeat yang memberikan pertumbuhan paling optimal di lahan pascatambang bauksit. 


\section{Metode Penelitian}

\subsection{Lokasi dan Waktu Penelitian}

Lokasi penelitian terletak di lahan pascatambang bauksit milik PT. Dinamika Sejahtera yang berada di Desa Teraju, Kecamatan Toba, Kabupaten Sanggau, Provinsi Kalimantan Barat pada titik koordinat S 0¹7'03.1" dan E 110²'51.4”, dengan batas kajian seluas $100 \mathrm{~m}^{2}$ dan dilaksanakan pada 28 september 2020 - 28 Oktober 2020.

\subsection{Alat dan Bahan}

Alat yang digunakan dalam penelitian ini antara lain adalah bor tanah, meteran, kantong plastik, buku, alat tulis, dan GPS Garmin. Bahan yang digunakan dalam penelitian ini antara lain cocopeat sebanyak 7 $\mathrm{kg}$, topsoil sebanyak $4 \mathrm{~kg}$, tanah pascatambang bauksit sebanyak $2 \mathrm{~kg}$, tanaman sengon (Paraserianthes falcataria) sebanyak 15 buah, kotoran ayam sebanyak $5 \mathrm{~kg}$, arang sekam sebanyak $5 \mathrm{~kg}$.

\subsection{Pengambilan dan Pengujian Sampel Tanah dan Cocopeat}

Terdapat 2 jenis sampel tanah yang diambil untuk dilakukan pengujian yaitu:

1. Sampel tanah di lahan pascatambang bauksit yang tidak memiliki topsoil dengan ciri ciri tanah bertekstur padat, keras, dan bebatuan.

2. Tanah yang masih memiliki topsoil yang diambil dari lahan yang belum digunakan sebagai tambang bauksit sehingga masih terdapat topsoil dengan ciri tanah bagian paling atas dengan warna cenderung lebih gelap dan terlihat gembur.

Sampel tanah yang akan diambil merupakan jenis sampel tanah tidak utuh (disturbed soil sample). Sampel tanah akan dikemas menggunakan kantong plastik tebal. Kemudian diberi keterangan informasi menggunakan label yang ditempelkan diluar kantong plastik mengenai titik koordinat, lokasi dan tanggal pengambilan, kedalaman tanah saat pengambilan. Teknik sampling yang akan digunakan adalah teknik sampling secara komposit. Pengambilan contoh tanah komposit adalah teknik pengambilan contoh tanah pada beberapa titik pengambilan (Suganda, 2002).

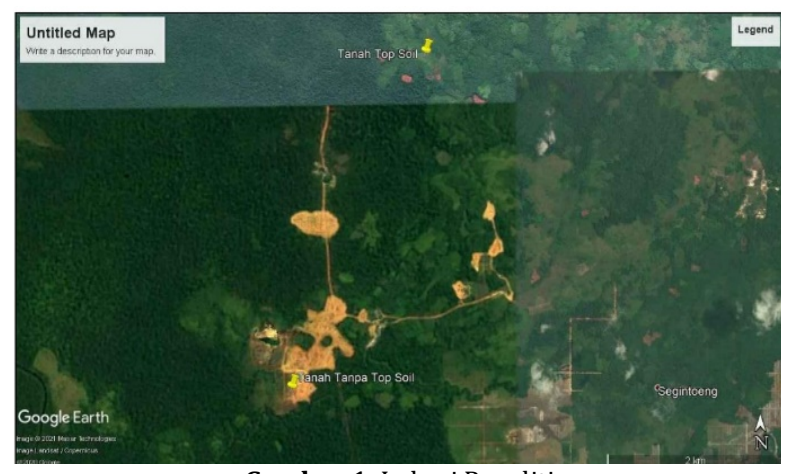

Sumber: Google Earth
Sampel tanah akan diambil dari 5 titik pengambilan untuk 1 sampel yang dikompositkan pada setiap lahan. Tanah diambil sedalam $20 \mathrm{~cm}$ dari lahan yang akan diamati. Kemudian contoh-contoh tersebut disatukan dan dicampur/diaduk sampai merata, kemudian dianalisis (Suganda, 2002). Sampel tanah yang diuji merupakan sampel tanah sebelum perlakuan dan sesudah dilakukan perlakuan berupa penanaman tanaman sengon. Sampel tanah dan cocopeat yang sudah di ambil kemudian masing masing dianalisis sifat kimia dan fisik tanahnya. Sifat kimia tanah yang akan dianalisis adalah $\mathrm{pH}, \%$ C-organik, KTK, $\mathrm{P}_{2} \mathrm{O}_{5}$, dan $\mathrm{N}$ total dan sifat fisik tanah yang akan dianalisis adalah kadar debu, pasir, dan liat dan akan dianalisis di Laboratorium Kimia dan Kesuburan Tanah Fakultas Pertanian Universitas Tanjungpura. Total sampel tanah yang diuji sebanyak 23 sampel yang terdiri 1 sampel cocopeat dan 22 sampel tanah dari 5 perlakuan dengan masing-masing perlakuan dilakukan pengulangan sebanyak 3 kali.

\subsection{Preparasi Media Tanam Cocopeat sebelum digunakan}

Sebelum digunakan, cocopeat harus dicuci dengan air bersih terlebih dahulu sampai hilangnya busa busa putih dan air menjadi jernih untuk menghilangkan zat tanin yang masih tertinggal di dalam cocopeat. Setelah dicuci cocopeat harus dikeringkan terlebih dahulu dengan cara dijemur selama 3 hari dibawah terik matahari hingga kering sebelum digunakan.

\subsection{Preparasi Lahan Pascatambang yang digunakan}

Menyiapkan lubang sedalam $60 \mathrm{~cm}$ dengan ukuran $30 \mathrm{~cm}$ x $30 \mathrm{~cm}$ sebanyak 12 lubang tanam dilahan tanpa topsoil dan 3 lubang tanam di lahan yang masih terdapat topsoil dengan jarak masing-masing 3 meter kemudian setiap lubang diberi perlakuan. Variasi perlakuan yang akan digunakan adalah sebagai berikut:

$1.100 \%$ cocopeat tanpa penambahan arang sekam dan kotoran ayam sebagai uji control.

2. $50 \%$ cocopeat dari volume lubang serta $25 \%$ arang dan $25 \%$ kotoran ayam.

3. $60 \%$ cocopeat dari volume lubang serta $25 \%$ arang dan $15 \%$ kotoran ayam.

Masing masing perlakuan dilakukan sebanyak 3 kali pengulangan.

\subsection{Penanaman Bibit Sengon}

Preparasi penelitian dimulai dengan persiapan alat yang akan digunakan serta penyediaan bibit tanaman sengon (Parasianthes Falcataria) berusia 3 bulan lalu dimasukkan kedalam lubang yang berisi media tanam sesuai variasi perlakuan. Bibit ditanam dengan kondisi tegak lurus. Polibag dengan hati hati dibuka terlebih dahulu agar tidak terjadi kerusakan media tanam, agar tidak ada genangan air ketika 
musim hujan maka leher akar harus lebih tinggi sedikit dari permukaan tanah. Proses penanaman dilakukan di Lahan pascatambang bauksit tanpa diberikan perlakuan media tanam, lahan yang masih tersedia topsoil, dan lahan pascatambang yang diberi perlakuan media tanam. Pemeliharaan dilakukan selama tanaman di dalam lubang adalah penyiraman berdasarkan hari hujan. Pengamatan akan dilakukan selama 28 hari. Perubahan yang diukur dan diamati untuk mengetahui pengaruh media tanam terhadap pertumbuhan tanaman adalah pertambahan tinggi tanaman dan jumlah cabang daun yang diamati setiap 7 hari sekali yang dimulai dari minggu ke-0 dari tanaman ditanam ke dalam tanah.

\section{Hasil dan Pembahasan}

\subsection{Kondisi Eksisting Lahan Pascatambang}

PT. Dinamika Sejahtera Mandiri merupakan perusahaan yang bergerak di bidang penambangan bauksit yang terletak di Desa Toba, Kecamatan Teraju, Kabupaten Sanggau Provinsi Kalimantan Barat. Kegiatan penambangan akan menimbulkan kerusakan lingkungan seperti yang terjadi di lahan tambang bauksit milik PT. Dinamika Sejahtera Mandiri. Kondisi kimia, fisik dan biologi pada lahan pascatambang bauksit yang mengalamai penurunan mengindikasikan telah terjadi degradasi di lahan tersebut. Soebardja (2009) menyatakan bahwa lahan pascatambang bauksit yang dilakukan dengan sistem open pit mining memiliki kondisi yaitu rendahnya kesuburan tanah, mudah terjadi erosi, sulitnya vegetasi untuk tumbuh karena rendahnya daya dukung tanah serta kondisi permukaan lahan yang tidak teratur. Sedangkan menurut Hermawan (2002) dalam Refliaty (2018), selama proses penambangan lahan dilintasi oleh alatalat berat dan adanya sistem penimbunan yang menyebabkan terbentuknya lapisan padat pada bagian permukaan tanah sehingga menutup pori-pori tanah (surface sealing and crusting). Kondisi lahan pascatambang bauksit yang berada di Desa Teraju dapat dilihat pada Gambar 2. Dapat dilihat bahwa kondisi lahan pascatambang bauksit sangat kering, tidak ada vegetasi, sebagian besar merupakan bebatuan, tanah yang keras serta sulit menyerap air.

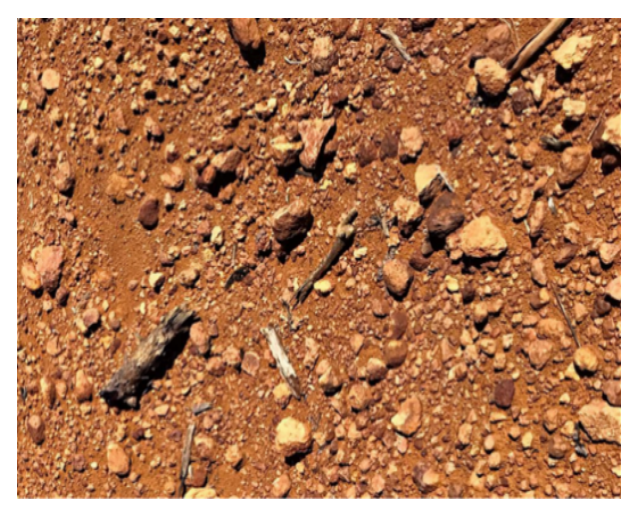

Gambar 2. Kondisi Lahan di Lokasi Penelitian
Tabel 1. Kondisi Fisik dan Kimia Tanah di Lahan Pascatambang Bauksit di Desa Teraju, Kalimantan Barat

\begin{tabular}{|c|c|c|c|}
\hline No & Parameter & Nilai & Status Kesuburan \\
\hline 1 & PH & 4,34 & Sangat rendah \\
\hline 2 & C-Organik & 0,98 & Sangat rendah \\
\hline 3 & N-Total & 0,13 & Sangat rendah \\
\hline 4 & P205 & 3,04 & Sangat rendah \\
\hline 5 & KTK & 3,8 & Sangat rendah \\
\hline \multirow{4}{*}{6} & \multicolumn{3}{|c|}{ Tekstur: } \\
\hline & Pasir & 15,45 & - \\
\hline & Debu & 49,08 & - \\
\hline & Liat & 35,47 & - \\
\hline
\end{tabular}

Sumber: Hasil Analisis Laboratorium Fakultas Pertanian UNTAN 2020.

Kondisi lahan menjadi kritis karena proses penambangan yang mengupas tubuh tanah bagian atas sehingga lahan menjadi miskin hara dan kering, karena tanah sulit menyimpan air dan sulit diolah. Hal ini sesuai dengan pernyataan Whitemore et al (2011) bahwa dalam kondisi lahan yang rusak, hampir semua jenis tanaman akan sulit tumbuh dengan baik karena pergerakan akar untuk menyerap air dan nutrisi menjadi terbatas. Penutupan pori-pori tanah menjadi faktor penghambat proses infiltrasi air hujan dan irigasi ke dalam tanah. Kondisi tersebut mendorong untuk terbentuknya kerak (crust formation) dan pengkerasan tanah sebagai akibat minimnya kandungan air di dalam badan tanah. Dampak negatifnya adalah terhambatnya perkecambahan benih tanaman. Kegiatan rehabilitasi harus dilakukan pada lahan pasca penambangan, agar degradasi tidak berlanjut ke kondisi yang lebih parah.

Kondisi fisik dan kimia tanah juga mempengaruhi keberhasilan revegetasi. Jenis tanah di lokasi penelitian adalah tanah latosol. Menurut Saptiningsih dan Haryanti (2015), tanah dengan jenis latosol adalah tipe tanah yang memiliki karakteristik $\mathrm{pH}$ yang rendah serta minim kandungan hara dan material organik serta mengalami proses pelapukan lanjut. Hal ini sesuai dengan hasil analisis kondisi fisik dan kimia tanah di lahan pascatambang bauksit di Desa Teraju yang diuji di Laboratorium Kesuburan Tanah Fakultas Pertanian Universitas Tanjungpura dapat dilihat pada Tabel 1.

Hasil pengukuran $\mathrm{pH}$ tanah menunjukan bahwa nilai $\mathrm{pH}$ tanah di lahan pascatambang cukup asam. Menurut Sembiring (2008), kegiatan pencucian topsoil yang masih bercampur dengan bauksit dalam proses penambangan menyebabkan tanah topsoil terbawa air cucian sehingga tailing bauksit minim kandungan tanah. Lahan yang banyak memiliki kandungan bauksit sulit untuk menahan air karena fraksi penyusunnya adalah pasir dan batu kerikil. Dampaknya pada lahan pascatambang bauksit adalah adalah terjadinya penurunan $\mathrm{pH} \mathrm{H}_{2} \mathrm{O}$ tanah. Hasil dari pengukuran parameter kadar C-Organik juga sangat rendah. Kadar C-Organik merupakan dari kandungan bahan di dalam tanah. Berdasarkan pendapat Sutedjo et al (2002) dalam Ramadhana et al (2019) kandungan C-Organik 
di dalam tanah rendah maka kandungan bahan organiknya juga sangat rendah. Menurut Sembiring (2008), penurunan kandungan bahan organik pada lahan pascatambang bauksit disebabkan larutnya $\mathrm{C}$ organik bersamaan dengan terbawanya tanah oleh air saat proses pemisahan tanah dengan bauksit melalui metode pencucian. Menurut Wydiantara dkk., (2015), kadar kandungan bahan dan $\mathrm{pH}$ mempengaruhi nilai KTK. Jika nilai KTK rendah maka nilai pH dan kadar Corganik juga rendah. Hal ini juga diperkuat dari hasil penelitian Hardjwigeno (2002) dalam Suryani (2014) pH tanah mempengaruhi pertukaran kation. Pada kondisi $\mathrm{pH}$ rendah, maka muatan ion yang dapat dipertukarkan adalah muatan koloid memegang ion dan muatan permanen liat, dengan demikian KTK menjadi rendah. Teori diatas sesuai dengan hasil uji kualitas tanah yang menunjukan bahwa nilai kadar KTK rendah, dimana nilai uji $\mathrm{pH}$ dan C-organik di Lahan Pascatambang bauksit juga menunjukkan nilai yang sangat rendah.

Kandungan fosfor $\left(\mathrm{P}_{2} \mathrm{O}_{5}\right)$ dan $\mathrm{N}$ total pada lahan pascatambang tergolong rendah. Kegiatan penambangan menyebabkan hilangnya bahan organik di dalam tanah karena hilangnya tanah lapisan atas yang mengandung bauksit dicuci dengan air sehingga tanah yang mengandung bahan organik dan nitrogen larut dalam air waktu pencucian, yang juga dapat menurunkan kandungan nitrogen pada lahan pascatambang. Hal ini sesuai dengan penelitian Hardjowigeno (2003) dalam Mustafa (2012) yang menyatakan sisa tanaman serta pupuk kandang maupun pupuk kimia (TSP) dan mineral dalam tanah dapat menghasilkan unsur fosfor.

Kandungan tekstur liat pada tanah pascatambang cukup rendah dan kadar debu yang tinggi disebabkan oleh tidak adanya vegetasi sehinggga kandungan bahan organik rendah dan tanah cenderung kering karena sedikitnya kandungan kadar air yang ada di dalam tanah. Hal ini sesuai dengan pernyataan Hakim et al. (1986) dalam Soniari (2016) menyatakan bahwa fraksi liat memiliki luas permukaan spesifik yang besar sehingga meningkatkan daya adsorbsi terhadap molekul air dan kation. Oleh karena itu, tanah dengan kandungan liat tinggi memiliki kecendrungan kadar air, bahan organik dan KTK juga tinggi.

\subsection{Perbandingan Karakteristik Sifat Fisik dan Kimia Tanah antara Tanah Topsoil, Tanah Lahan Pascatambang Bauksit, dan Cocopeat.}

Berdasarkan observasi melalui pengambilan sampel awal tanah topsoil, tanah lahan pascatambang bauksit, dan cocopeat maka dilakukan uji karakteristik sifat fisik dan kimia tanah untuk kemudian dianalisis dan dibandingkan hasil uji kualitasnya. Perbandingan dilakukan untuk mengetahui karakteristik cocopeat sebagai pengganti tanah jika dibandingkan dengan tanah topsoil dan pascatambang. Hasil perbandingan uji parameter dari ketiga sampel dapat dilihat pada Tabel 2.

Kandungan $\mathrm{pH}$ cocopeat lebih tinggi daripada tanah topsoil dan tanah pascatambang bauksit yaitu sebesar 5,02. Parameter $\mathrm{pH}$ ketiga sampel ini masih termasuk dalam kategori asam. Cocopeat memiliki kandungan parameter C-organik tertinggi dibandingkan tanah topsoil dan tanah pascatambang bauksit. Hal ini menunjukkan bahwa cocopeat dapat memperbaiki kondisi tanah pascatambang yang rusak karna tingginya kandungan bahan yang sesuai dengan pendapat Tate (1987) dalam Rajiman, dkk (2008) dalam Hasibuan (2015) salah satu bahan yang digubajab dalam perbaikan sifat fisik, kimia dan biologi tanah adalah bahan organik karna secara fisik dapat memperbaiki serta meningkatkan struktur dan perkembangan tanah serta berperan sebagai pemebntuk agregat tanah. Nilai parameter $\mathrm{N}$ - Total untuk cocopeat dan tanah topsoil tidak jauh berbeda tetapi masih termasuk rendah, ketersediaan nitrogen terendah yaitu pada tanah pascatambang. Nitrogen $(\mathrm{N})$ mempunyai peran penting bagi pertumbuhan tanaman. Nitrogen dapat diserap tanaman. Rendahnya ketersediaan nitrogen dalam tanah dapat membuat vegetasi sulit tumbuh.

Tabel 2. Perbandingan Karakteristik Sifat Fisik dan Kimia Tanah antara Tanah Topsoil, Tanah Lahan Pascatambang Bauksit, dan Cocopeat.

\begin{tabular}{|c|c|c|c|c|c|c|c|}
\hline \multirow[t]{2}{*}{ No } & \multirow[t]{2}{*}{ Parameter } & \multicolumn{4}{|c|}{ "Tanah Topsoil (Perlakuan A) } & \multirow{2}{*}{$\begin{array}{c}\text { Tanah pascatambang } \\
\text { bauksit }\end{array}$} & \multirow[t]{2}{*}{ Cocopeat } \\
\hline & & $\mathrm{A} 1$ & $\mathrm{~A} 2$ & A3 & Rata-Rata & & \\
\hline 1 & $\mathrm{PH}$ & 4,69 & 4,56 & 4,67 & 4,64 & 4,33 & 5,02 \\
\hline 2 & C-Organik & 3,32 & 2,97 & 3,12 & 3,14 & 0,98 & 55,87 \\
\hline 3 & N-Total & 0,47 & 0,42 & 0,44 & 0,44 & 0,13 & 0,49 \\
\hline 4 & P205 & 10,21 & 10,17 & 9,00 & 9,79 & 3,04 & 7,95 \\
\hline 5 & KTK & 12,91 & 11,55 & 12,13 & 12,20 & 3,8 & 86,47 \\
\hline \multirow[t]{4}{*}{6} & \multicolumn{7}{|c|}{ Tekstur: } \\
\hline & Pasir & 49,48 & 50,59 & 42,46 & 47,51 & 15,45 & 15,5 \\
\hline & Debu & 28,87 & 28,89 & 33,83 & 30,53 & 49,08 & 52,6 \\
\hline & Liat & 21,65 & 21,65 & 23,71 & 22,33 & 35,47 & 31,9 \\
\hline
\end{tabular}

Sumber: Hasil Analisis Laboratorium Fakultas Pertanian UNTAN, 2020 
Kadar $\mathrm{P}_{2} \mathrm{O}_{5}$ tertinggi yaitu pada tanah topsoil dan kandungan terendah terdapat pada tanah pascatambang. Nilai $\mathrm{P}_{2} \mathrm{O}_{5}$ pada cocopeat tidak jauh berbeda daripada tanah topsoil. Kandungan KTK pada cocopeat termasuk sangat tinggi. KTK atau Kapasitas Tukar Kation adalah sifat kimia tanah yang memiliki kaitan erat dengan adanya ketersediaan hara untuk tanaman serta sebagai acuan dalam kesuburan tanah. KTK merupakan kapasitas lempung yang dapat menjerap serta menukar kation serta menunjukan kation-kation tanah seperti $\mathrm{Na}$, Ca dan $\mathrm{Mg}$ yang dapat diserap dan ditukar oleh perakaran tanaman (Herawati, 2015), karena tingginya nilai KTK pada cocopeat maka, cocopeat dapat dijadikan sebagai pengganti tanah topsoil dalam memperbaiki kualitas tanah pascatambang yang rusak. Menurut Soniari (2016) fraksi liat berkorelasi positif sangat nyata dengan kadar air tanah dan KTK tanah, namun pada penelitian ini kandungan kadar liat cocopeat lebih rendah daripada tanah pascatambang bauksit meskipun cocopeat memiliki kadar KTK yang lebih tinggi. Hal ini dikarenakan cocopeat termasuk ke dalam bahan organik sehingga memiliki kadar liat rendah yang merupakan karakteristik fisik tekstur tanah. Tingginya kandungan bahan organik pada cocopeat diduga mempengaruhi nilai KTK menjadi tinggi meskipun kadar liatnya rendah.

\subsection{Revegetasi Menggunakan Tanaman Sengon Dalam Upaya Perbaikan Lahan Pascatambang Bauksit}

Perbaikan upaya lahan pascatambang bauksit dimulai dengan melakukan survey dan perizinan untuk menggunakan lahan sebagai lokasi penelitian. Lahan yang digunakan terdiri dari 2 lokasi yaitu lokasi yang masih memiliki topsoil serta vegetasi dan belum digunakan sebagai penambangan bauksit dan lokasi yang sudah tidak terdapat topsoil serta telah dilakukan penambangan di lokasi tersebut. Upaya yang dilakukan dalam perbaikan lahan pascatambang berupa revegetasi. Sebelum dilakukan revegetasi lahan harus dibersihkan terlebih dahulu agar dapat digunakan. Proses revegetasi menggunakan tanaman sengon. Pemilihan tanaman yang adaptif, cocok dan sesuai dengan karakteristik lahan bekas tambang juga menjadi kunci pokok penentu keberhasilan proses reklamasi lahan bekas tambang. Oleh karena itu, tipe tanaman yang digunakan dalam revegetasi dipilih berdasarkan jenis tanaman yang cepat bertumbuh, kanopi yang rindang, akar yang kuat serta mudah beradabtasi dengan lingkungan baru.

Tanaman sengon juga berfungsi sebagai awal untuk meningkatkan iklim mikro sehingga cocok untuk ekosistem lahan pasca tambang, oleh karena itu, upaya perbaikan lahan yang dilakukan berupa reklamasi lahan pascatambang bauksit menggunakan tanaman sengon dengan menggunakan cocopeat sebagai pengganti topsoil yang hilang akibat proses penambangan terbuka (open pit mining). Menurut penelitian Taqiyuddin (2020) Jenis tanaman yang paling adaptif untuk ditanam di lahan reklamasi bekas tambang adalah tanaman sengon. Tanaman sengon dipilih sebagai tanaman reklamasi karena tanaman ini mudah tumbuh di berbagai tipe serta karakteristik tanah karna tidak memerlukan kondisi tanah yang subur, selain itu dapat bertumbuh di tanah yang kering bahkan masam selama kebutuhan air tanaman tercukupi selain itu tanaman ini termasuk tanaman cepat tumbuh (Fast Growing Species) (Soerianegara dan Lemmens, 1993).

Laju infiltrasi air dan jumlah udara dalam tanah dapat berkurang karena kondisi tanah yang keras dan padat sehingga dapat menghambat pertumbuhan akar tanaman. Diperlukan sirkulasi air dan udara yang baik agar perkembangan akar tanaman dapat terjamin. Jika tanah memiliki tingkat kegemburan dan struktur yang baik maka pertumbuhan akar tanaman juga akan maksimal, Hal ini dapat didapatkan dengan menambahkan bahan organik ke dalam tanah karena dapat meningkatkan konsistensi gembur tanah oleh tanah yang memiliki kandungan bahan organik tinggi.

Cocopeat memiliki kemampuan menyerap air, menggemburkan tanah serta menyimpan dan melepas nutrisi untuk tanaman. Oleh karena itu cocopeat dipilih sebagai media tanam yang akan digunakan dalam penelitian ini. Sengon yang digunakan memiliki tinggi berkisar $60 \mathrm{~cm}-90 \mathrm{~cm}$. Sebelum dilakukan penanaman di lokasi penelitian, tanaman sengon diberikan proses adaptasi berupa didiamkan di tempat teduh dari dalam pot semai selama 1 minggu yang bertujuan untuk menseleksi bibit sengon mana yang dapat bertahan. Sengon ditanami sesuai variasi perlakuan yang digunakan dengan kombinasi media tanam cocopeat, arang sekam dan kotoran ayam.

\subsection{Hasil Pemantauan Kondisi Fisik Berdasarkan Pertambahan Tinggi Tanaman Sengon}

Pertambahan tinggi tanaman Sengon didapatkan dari data hasil pengukuran tinggi tanaman dengan mengukur tinggi tanaman dari tanah hingga ujung tanaman menggunakan alat ukur meteran setiap seminggu sekali selama 1 bulan. Pertambahan tinggi tanaman dihitung menggunakan data hasil pengukuran tinggi tanaman di minggu terakhir pemantauan (akhir bulan) dikurangi dengan data hasil pengukuran tinggi tanaman di minggu awal pemantauan yaitu saat awal penanaman tanaman. Hasil pemantauan dapat dilihat pada Tabel 3.

Kode tanam D yaitu tanaman Sengon yang ditanam pada lahan tanpa topsoil dengan perlakuan 50\% cocopeat dari volume lubang serta penambahan $25 \%$ arang sekam dan 25\% kotoran ayam memiliki pertambahan tinggi tanaman tertinggi dibandingkan perlakuan tanam lainnya. Hal ini dilihat dari pertambahan tinggi tanaman kode tanaman D1 sebesar $18 \mathrm{~cm}$, diikuti pertambahan tinggi kode tanaman D2 sebesar $9 \mathrm{~cm}$ dan pertambahan tinggi kode tanaman D3 sebesar $14 \mathrm{~cm}$. 
Tabel 3. Pertambahan Tinggi Tanaman Sengon

\begin{tabular}{cccccccc}
\hline \hline Kode & \multicolumn{5}{c}{ Tinggi Tanaman (cm) } & $\begin{array}{c}\text { Pertambahan } \\
\text { Tanam }\end{array}$ & \multicolumn{5}{c}{ Minggu Ke- } & Rata-Rata \\
& 0 & 1 & 2 & 3 & 4 & & $\begin{array}{c}\text { Tinggi } \\
\text { han } \\
\text { Tinggi }\end{array}$ \\
\hline A1 & 48 & 49 & 49 & 49 & 50 & $2 \mathrm{~cm}$ & $3,3 \mathrm{~cm}$ \\
A2 & 57 & 57 & 59 & 63 & 63 & $6 \mathrm{~cm}$ & \\
A3 & 62 & 63 & 63 & 63 & 64 & $2 \mathrm{~cm}$ & \\
B1 & 52 & 52 & 53 & 54 & 54 & $2 \mathrm{~cm}$ & $1,6 \mathrm{~cm}$ \\
B2 & 55 & 56 & 57 & 57 & 57 & $2 \mathrm{~cm}$ & \\
B3 & 56 & 56 & 57 & 57 & 57 & $1 \mathrm{~cm}$ & \\
C1 & 62 & 64 & 65 & 65 & 65 & $3 \mathrm{~cm}$ & $5,6 \mathrm{~cm}$ \\
C2 & 64 & 69 & 70 & 70 & 70 & $6 \mathrm{~cm}$ & \\
C3 & 71 & 75 & 78 & 79 & 79 & $8 \mathrm{~cm}$ & \\
D1 & 51 & 52 & 66 & 67 & 69 & $18 \mathrm{~cm}$ & $13,7 \mathrm{~cm}$ \\
D2 & 62 & 65 & 68 & 70 & 71 & $9 \mathrm{~cm}$ & \\
D3 & 74 & 82 & 87 & 88 & 88 & $14 \mathrm{~cm}$ & \\
E1 & 54 & 58 & 66 & 68 & 69 & $15 \mathrm{~cm}$ & $10,33 \mathrm{~cm}$ \\
E2 & 70 & 71 & 75 & 75 & 76 & $6 \mathrm{~cm}$ & \\
E3 & 60 & 64 & 67 & 69 & 70 & $10 \mathrm{~cm}$ & \\
\hline
\end{tabular}

Kode tanam E yaitu tanaman Sengon yang ditanam pada lahan tanpa topsoil dengan perlakuan $60 \%$ cocopeat dari volume lubang serta penambahan $25 \%$ arang sekam dan $15 \%$ kotoran ayam juga mengalami pertambahan tinggi tanaman yang cukup tinggi. Hal ini dilihat dari kode tanam E1 dengan pertambahan tinggi tanaman sebesar $15 \mathrm{~cm}$, diikuti dengan kode tanam E2 sebesar $6 \mathrm{~cm}$, kode tanam E3 sebesar $1 \mathrm{~cm}$.

Berdasarkan uraian di atas, kode tanam D memiliki pengaruh yang lebih signifikan terhadap pertambahan tinggi tanaman dibandingkan dengan kode tanam E. Meskipun begitu, hal ini menunjukkan bahwa kemampuan cocopeat sebagai pengganti topsoil dikatakan baik dilihat dari pertambahan tinggi tanaman Sengon pada kode tanam D dan E yang cukup signifikan, sehingga dapat dikatakan bahwa kandungan hara dan bahan organik yang terdapat pada cocopeat mampu mengganti kemampuan tanah topsoil. Hal ini sesuai dengan penelitian Saputra dkk (2016) yang menyatakan bahwa cocopeat memberi pengaruh yang nyata terhadap pertambahan tinggi tanaman. Dosis yang seimbang dalam pemberian kompos dan cocopeat dapat memperbaiki sifat kimia dan fisik tanah seperti meningkatkan ketersediaan hara makro dan mikro dan perbaikan struktur tanah, daya simpan air, dan pertukaran udara (aerasi tanah) Hasil pemantauan dari kondisi fisik pada kode tanam B yaitu tanaman Sengon yang ditanam pada lahan tanpa topsoil tanpa perlakuan memiliki pertambahan tinggi tanaman yang paling rendah.

Hal ini dilihat dari data yang disajikan pada Tabel 3 dengan pertambahan tinggi kode tanam B1 sebesar 2 $\mathrm{cm}$, pertambahan tinggi kode tanam B2 sebesar $2 \mathrm{~cm}$, dan pertambahan tinggi kode tanam B3 sebesar $1 \mathrm{~cm}$. Pertambahan tinggi yang rendah menunjukkan bahwa kondisi tanah tidak subur karena kandungan hara dan bahan organik pada tanah rendah sehingga tidak memberikan pertambahan tinggi yang signifikan. Hal ini membuktikan bahwa kondisi lahan tambang pasca bauksit memiliki kualitas tanah yang buruk serta rendah akan bahan organik dan kandungan hara, sehingga berdampak bagi pertambahan tinggi tanaman. Hal ini sesuai dengan penelitian Sittadewi (2016) yang menyatakan bahwa perubahan kondisi kimia tanah seperti kesuburan tanah, rendahnya kadar nutrisi, unsur hara seperti $\mathrm{N}$ dan $\mathrm{P}$ serta asamnya reaksi tanah dapat terjadi perubahan karna adanya kegiatan penambangan hal ini mengakibatkan sulitnya vegetasi untuk tumbuh.

\subsection{Hasil Pemantauan Kondisi Fisik Berdasarkan Jumlah Daun Tanaman Sengon}

Jumlah daun tanaman Sengon didapatkan dari data hasil peninjauan secara langsung pada tanaman Sengon dengan menghitung jumlah cabang daun pada tanaman setiap seminggu sekali selama 1 bulan. Perhitungan jumlah cabang daun dihitung berdasarkan jumlah cabang daun tanaman Sengon di akhir pemantauan (pada minggu ke-4) dikurangi dengan jumlah cabang daun tanaman Sengon di awal pemantauan (pada minggu ke-0). Hasil pemantauan dapat dilihat pada Tabel 4.

Pertambahan jumlah cabang daun terjadi pada tanaman dengan kode tanam D, yaitu tanaman Sengon yang ditanam pada lahan tanpa topsoil dengan perlakuan 50\% cocopeat dari volume lubang serta penambahan 25\% arang sekam dan 25\% kotoran ayam. Pertambahan jumlah cabang daun dengan kode tanam D terjadi pada kode tanam D1 sebanyak 18 helai. Pada kode tanam D2, terjadi pertambahan jumlah cabang daun sebanyak 4 helai, dan pertambahan jumlah cabang daun pada kode tanam D3 sebanyak 13 helai. Hal ini menunjukkan bahwa pada kode tanam D memiliki pertambahan jumlah cabang daun yang paling signifikan dibandingkan kode tanam yang lainnya. Meskipun terdapat pengurangan jumlah cabang daun dalam jumlah yang sedikit pada kode tanam E2 dan kode tanam E3, namun pada kode tanam E1 terjadi pertambahan jumlah cabang daun yang cukup banyak, yaitu sebanyak 19 helai. Hal ini menunjukkan bahwa kode tanam E yaitu tanaman Sengon yang ditanam pada lahan tanpa topsoil dengan perlakuan 60\% cocopeat dari volume lubang serta penambahan $25 \%$ arang sekam dan $15 \%$ kotoran ayam memiliki pertambahan jumlah cabang daun yang cukup baik dibandingkan kode tanam A, kode tanam B, kode tanam C. dapat disimpulkan bahwa pertambahan jumlah cabang daun tanaman Sengon terjadi pada perlakuan kode tanam D kode tanam E. Selain pertambahan jumlah cabang daun, kondisi fisik daun pada kode tanam D kode tanam E memiliki bentuk daun yang lebar dan rimbun. Hal ini menunjukkan bahwa kemampuan cocopeat sebagai pengganti topsoil dikatakan baik dilihat dari pertambahan jumlah cabang daun tanaman Sengon pada kode tanam D dan E, sehingga dapat dikatakan bahwa kandungan hara dan bahan organik yang terdapat pada cocopeat mampu mengganti kemampuan tanah topsoil. Hal ini sesuai dengan penelitian Saputra dkk (2016) yang menyatakan bahwa pemberian cocopeat memberi pengaruh yang nyata terhadap tinggi tanaman. 
Tabel 4. Pertambahan Cabang Daun Sengon

\begin{tabular}{|c|c|c|c|c|c|c|c|}
\hline \multirow[t]{2}{*}{$\begin{array}{l}\text { Kode } \\
\text { Tanam }\end{array}$} & \multicolumn{5}{|c|}{$\begin{array}{l}\text { Pertambahan } \\
\text { Cabang Daun } \\
\text { Minggu Ke- }\end{array}$} & \multirow{2}{*}{$\begin{array}{c}\text { Perhitungan } \\
\text { Jumlah Cabang } \\
\text { Daun }\end{array}$} & \multirow[t]{2}{*}{ Keterangan } \\
\hline & 0 & 1 & 2 & 3 & 4 & & \\
\hline A1 & 5 & 8 & 6 & 3 & 3 & $\begin{array}{c}\text { Pengurangan } 2 \\
\text { helai }\end{array}$ & \multirow{3}{*}{$\begin{array}{c}\text { terjadi } \\
\text { pengurangan } \\
\text { rata-rata } \\
\text { sebanyak } 1 \\
\text { helai }\end{array}$} \\
\hline $\mathrm{A} 2$ & 6 & 6 & 6 & 4 & 5 & $\begin{array}{c}\text { Pengurangan } 1 \\
\text { helai }\end{array}$ & \\
\hline A3 & 6 & 4 & 5 & 6 & 6 & Tetap (0 helai) & \\
\hline B1 & 6 & 4 & 1 & 1 & 1 & $\begin{array}{c}\text { Pengurangan } 5 \\
\text { helai }\end{array}$ & \multirow{3}{*}{$\begin{array}{c}\text { terjadi } \\
\text { pengurangan } \\
\text { rata-rata } \\
\text { sebanyak } 4 \\
\text { helai }\end{array}$} \\
\hline B2 & 7 & 1 & 2 & 2 & 2 & $\begin{array}{c}\text { Pengurangan } 5 \\
\text { helai }\end{array}$ & \\
\hline B3 & 5 & 3 & 3 & 2 & 2 & $\begin{array}{c}\text { Pengurangan } 3 \\
\text { helai }\end{array}$ & \\
\hline C1 & 4 & 4 & 5 & 5 & 5 & $\begin{array}{c}\text { Pertambahan } 1 \\
\text { helai }\end{array}$ & \multirow{3}{*}{$\begin{array}{c}\text { terjadi } \\
\text { pertambahan } \\
\text { rata-rata } \\
\text { sebanyak } 4 \\
\text { helai }\end{array}$} \\
\hline $\mathrm{C} 2$ & 3 & 3 & 8 & 4 & 6 & $\begin{array}{l}\text { Pertambahan } 3 \\
\text { helai }\end{array}$ & \\
\hline $\mathrm{C} 3$ & 8 & 7 & 10 & 8 & 6 & $\begin{array}{c}\text { Pengurangan } 2 \\
\text { helai }\end{array}$ & \\
\hline D1 & 7 & 8 & 16 & 18 & 18 & $\begin{array}{l}\text { Pertambahan } 11 \\
\text { helai }\end{array}$ & \multirow{3}{*}{$\begin{array}{c}\text { terjadi } \\
\text { pertambahan } \\
\text { rata-rata } \\
\text { sebanyak } 6 \\
\text { helai }\end{array}$} \\
\hline D2 & 6 & 2 & 5 & 9 & 10 & $\begin{array}{c}\text { Pertambahan } 4 \\
\text { helai }\end{array}$ & \\
\hline D3 & 4 & 9 & 11 & 15 & 17 & $\begin{array}{c}\text { Pertambahan } 13 \\
\text { helai }\end{array}$ & \\
\hline E1 & 3 & 8 & 17 & 19 & 22 & $\begin{array}{l}\text { Pertambahan } 19 \\
\text { helai }\end{array}$ & \multirow{3}{*}{$\begin{array}{c}\text { terjadi } \\
\text { pertambahan } \\
\text { rata-rata } \\
\text { sebanyak } 5 \\
\text { helai }\end{array}$} \\
\hline E2 & 3 & 3 & 2 & 2 & 0 & $\begin{array}{c}\text { Pengurangan } 3 \\
\text { helai }\end{array}$ & \\
\hline E3 & 12 & 12 & 6 & 9 & 10 & $\begin{array}{c}\text { Pengurangan } 2 \\
\text { helai }\end{array}$ & \\
\hline
\end{tabular}

Pengurangan jumlah cabang daun yang signifikan terjadi pada tanaman dengan kode tanam B, yaitu tanaman Sengon yang ditanam pada lahan tanpa topsoil tanpa perlakuan. Pengurangan jumlah cabang daun dengan kode tanam B terjadi pada kode tanam B1 sebanyak 5 helai, kode tanam B2 sebanyak 5 helai, kode tanam B3 sebanyak 3 helai. Hal ini menunjukkan bahwa pada kode tanam B memiliki pengurangan jumlah cabang daun yang paling signifikan dibandingkan kode tanam yang lainnya. Selain itu, kondisi fisik daun pada kode tanam B memiliki bentuk daun yang layu dan kering. Hal ini menunjukkan bahwa kondisi tanah pada lahan pascatambang bauksit tidak subur karena kandungan hara dan bahan organik pada tanah rendah sehingga terjadi pengurangan jumlah cabang daun yang mengindikasikan ketidaksuburan kualitas tanah dilihat dari bentuk daun yang kering dan layu.

\subsection{Hasil Uji Parameter pH Sebelum dan Sesudah perlakuan}

Reaksi tanah dalam alkalinitas atau menujukan keasaman tanah disebut $\mathrm{pH}$ tanah. Keberhasilan tanah dalam mudah tidaknya penyerapan unsur-unsur hara yang diserap oleh tanaman juga ditentukan oleh $\mathrm{pH}$. Hasil Uji Parameter pH dapat dilihat pada Tabel 5.
Tabel 5. Hasil Uji Parameter pH

\begin{tabular}{cccc}
\hline \hline Parameter PH & Kode Sampel & Sebelum & Sesudah \\
\cline { 2 - 4 } & A & 4,64 & 4,63 \\
B & 4,34 & 4,20 \\
C & 4,41 & 3,97 \\
D & 4,27 & 4,21 \\
E & 4,29 & 4,93
\end{tabular}

Sumber: Hasil Analisis Laboratorium Fakultas Pertanian UNTAN 2020

pH pada kode tanam A hingga E menunjukkan karakter tanah yang sangat asam $(<4,5)$ dan tidak ada perubahan signifikan dengan adanya perlakuan yang menambahkan cocopeat, arang sekam, dan kotoran ayam. Penyebab tanah bereaksi masam ( $\mathrm{pH}$ rendah) adalah karena miskinnya unsur hara dalam tanah yang memicu tanah menjadi masam serta tanah kekurangan Kalsium (CaO) dan Magnesium (MgO), pH paling rendah terdapat pada perlakuan $\mathrm{C}$ setelah 1 bulan proses penanaman dimana proses penanaman hanya menggunakan 100\% cocopeat hal ini tidak sesuai dengan hasil penelitian Saputra (2019) yang menyatakan bahwa cocopeat memiliki pH netral. Hal ini diduga karena pencucian cocopeat yang kurang bersih serta tercampur dengan tanah pascatambang yang memiliki pH yang asam. Penyebabnya yaitu pada daerah beriklim tropis basah, akan memiliki curah hujan yang tinggi sehingga secara alami mencuci unsur hara di dalam tanah kemudian menyebabkan $\mathrm{pH}$ tanah menjadi rendah (Puspita, 2015).

\subsection{Hasil Uji Parameter C-organik Sebelum dan Sesudah perlakuan}

C- organik adalah salah satu indikator kesuburan tanah berdasarkan kandungan bahan organiknya. Rendahnya kandungan bahan organik mengindikasikan bahwa tanah tersebut mengalami degradasi atau penurunan kualitas tanah. Sumber energi dari jasad renik yang berperan penting dalam penyediaan unsur hara tanaman bisa didapatkan dari kandungan bahan organik. (Nagur, 2017). Hasil Uji Parameter C-organik dapat dilihat pada Tabel 6. Terjadi penurunan kadar C-organik pada perlakuan A dan B yang tidak ada perlakuan namun terjadi pertambahan nilai C-Organik pada tanah yang diberi perlakuan penambahan cocopeat, arang sekam dan kotoran ayam dalam komposi tertentu.

Tabel 6. Hasil Uji Parameter C-organik

\begin{tabular}{cccc}
\hline \hline & Kode Sampel & Sebelum & Sesudah \\
\cline { 2 - 4 } & A & 3,14 & 2,52 \\
Parameter C- & B & 1,04 & 0,96 \\
Organik & C & 0,86 & 1,04 \\
& D & 0,92 & 1,57 \\
& E & 1,09 & 2,18 \\
\hline Sumber: Hasil Analisis Laboratorium Fakultas Pertanian UNTAN 2020
\end{tabular}

Sumber: Hasil Analisis Laboratorium Fakultas Pertanian UNTAN 2020 
Penambahan kandungan C-organik tertinggi terdapat pada perlakuan E yang memiliki komposisi cocopeat paling tinggi, meskipun memiliki kadar kandungan bahan organik tertinggi pertumbuhan perlakuan E dari segi tinggi tanaman dan pertambahan jumlah daun masih tidak sebaik perlakuan D hal ini dikarenakan perlakuan D memiliki komposisi penambahan pupuk organik dari kotoran ayam yang lebih banyak daripada perlakuan E. hal ini sesuai dengan penelitian Muswita, dkk (2008) yang menyatakan bahwa pemberian pupuk organik memberikan pengaruh yang nyata terhadap tinggi tanaman dan diameter batang tanaman sengon.

Produktivitas dan keberlanjutan umur tanaman dapat ditingkatkan dengan pemberian bahan organik, karena ketersediaan nutrisi tanaman dan kesuburan tanah terdekomposisi dari bahan organik. (Yulipriyanto, 2010). C- organik dan Nitrogen total memiliki hubungan yang erat dalam tanah karna adanya C-organik sebagai sumber energi, yang bila tersedia berlebihan dapat menghambat tumbuh kembang mikroorganisme karna $\mathrm{N}$-total juga akan meningkat yang berlebihan di dalam tanah. Peningkatan ini mengakibatkan terhambatnya proses pembentukan protein yang juga menghambat kegiatan jasad renik. Oleh karena itu tingkat pelapukan dan kecepatan penguraian bahan organik serta ketersediaan nutrisi dalam tanah dapat diketahui dari kandungan C-organik dan N-total. (Backhtiar, 2006).

\subsection{Hasil Uji Parameter N-Total Sebelum dan Sesudah perlakuan}

Nitrogen total merupakan unsur esensial hara makro yang menyusul sekitar $1,5 \%$ dari bobot tanaman serta memiliki fungsi utama sebagai pembentukan protein. Hasil Uji Parameter N-total dapat dilihat pada Tabel 7. Penurunan kadar N-total pada perlakuan A yang tidak ada perlakuan namun terjadi pertambahan nilai $\mathrm{N}$-total pada tanah yang diberi perlakuan penambahan cocopeat, arang sekam dan kotoran ayam dalam komposi tertentu. Penambahan kandungan $\mathrm{N}$-total tertinggi terdapat pada perlakuan E yang memiliki komposisi cocopeat tertinggi dimana unsur Nitrogen dalam tana sangat mudah hilang karna terserap oleh tanaman dan jasad renik serta tercuci dan menguap oleh air hujan (Hardjowigeno, 2003 dalam Mustafa, 2012).

Tabel 7. Hasil Uji Parameter N- Total

\begin{tabular}{lccc}
\hline \hline & Kode Sampel & Sebelum & Sesudah \\
\cline { 2 - 4 } & A & 0,44 & 0,36 \\
Parameter & $\mathrm{B}$ & 0,14 & 0,14 \\
N-Total & $\mathrm{C}$ & 0,12 & 0,15 \\
& $\mathrm{D}$ & 0,13 & 0,23 \\
& $\mathrm{E}$ & 0,14 & 0,31 \\
\hline $\begin{array}{l}\text { Sumber: Hasil Analisis Laboratorium Fakultas Pertanian UNTAN } \\
\text { 2020 }\end{array}$ & \multicolumn{2}{l}{}
\end{tabular}

Sumber: Hasil Analisis Laboratorium Fakultas Pertanian UNTAN 2020
Nitrogen bermanfaat dalam meningkatkan pertumbuhaan tanaman dalam fase vegetatif, selain itu juga berperan penting dalam pembentukan senyawa seperti asam amino, enzim, klorofil dan lemak (Susanto, 2005).

\subsection{Hasil Uji Parameter $\mathrm{P}_{2} \mathrm{O}_{5}$ Sebelum dan Sesudah perlakuan}

Hara essensial yang berperan penting bagi tanaman salah satunya adalah fospor (P). Fospor dalam tanah banyak terdapat dalam bentuk terjerap maka ketersediaan fospor yang dapat diserap tanaman sangat rendah, padahal tanaman sangat memperlukan fospor dalam tumbuh kembangnya. (Buckman dan Brady, 1974). Hasil Uji Parameter $\mathrm{P}_{2} \mathrm{O}_{5}$ dapat dilihat pada Tabel 8.

Tabel 8. Hasil Uji Parameter $\mathrm{P}_{2} \mathrm{O}_{5}$

\begin{tabular}{cccc}
\hline \hline $\begin{array}{c}\text { Parameter } \\
\mathrm{P}_{2} \mathrm{O}_{5}\end{array}$ & Kode Sampel & Sebelum & Sesudah \\
\cline { 2 - 4 } & $\mathrm{A}$ & 9,79 & 27,03 \\
$\mathrm{~B}$ & 4,55 & 11,52 \\
$\mathrm{C}$ & 1,43 & 15,14 \\
$\mathrm{D}$ & 3,72 & 30,77 \\
& E & 2,46 & 136,47 \\
\hline
\end{tabular}

Sumber: Hasil Analisis Laboratorium Fakultas Pertanian 2020.

Peningkatan kadar $\mathrm{P}_{2} \mathrm{O}_{5}$ pada setiap perlakun setelah ditanami, namun kadar fospor tertinggi terjadi pada perlakuan E dimana kadar fosfor tersebut mencapai 136,47 hal ini menunjukan bahwa menambahan bahan organik dapat meningkatkan ketersediaan P di dalam tanah.

\subsection{Hasil Uji Parameter KTK Sebelum dan Sesudah perlakuan}

Kapasitas Tukar Kation (KTK) merupakan salah satu sifat kimia tanah yang dapat menjadi indikator ketersediaan unsur hara dan kesuburan tanah (Gunawan dkk, 2019). Hasil Uji Parameter KTK dapat dilihat pada Tabel 9.

Tabel 9. Hasil Uji Parameter KTK

\begin{tabular}{cccc}
\hline \hline Parameter KTK & Kode Sampel & Sebelum & Sesudah \\
\cline { 2 - 3 } A & 12,20 & 11,85 \\
B & 4,04 & 4,51 \\
C & 3,34 & 4,89 \\
D & 3,58 & 7,40 \\
E & 4,24 & 10,23 \\
\hline
\end{tabular}

Sumber: Hasil Analisis Laboratorium Fakultas Pertanian UNTAN 2020.

Pengamatan nilai KTK menunjukkan bahwa nilai KTK tanah cenderung meningkat seiring dengan adanya perlakuan penambahan bahan organik seperti cocopeat, arang sekam dan kotoran ayam yang 
diberikan. Peningkatan nilai tertinggi terjadi pada perlakuan E namun masih lebih rendah jika dibandingkan perlakuan A yaitu kadar topsoil setelah ditanami. Peningkatan nilai tersebut dipengaruhi oleh perbedaan jumlah bahan organik (cocopeat) yang diberikan. Kombinasi perlakuan E memiliki kadar cocopeat yang lebih tinggi daripada perlakuan D, sehingga memiliki nilai KTK yang lebih tinggi. Cocopeat sendiri memiliki nilai KTK sebesar 86,47 me/100g.

Proses dekomposisi bahan organik akan menghasilkan asam-asam organik yang dapat menambah muatan negatif (anion) dalam koloid tanah sehingga muatan-muatan positif (kation) dapat dipertukarkan. Oleh karena itu, semakin banyak bahan organik yang diberikan pada tanah yang alkalis maka nilai KTK tanah akan meningkat karena banyaknya kation yang dapat dipertukarkan pada kompleks pertukaran. Pada perlakuan E nilai KTK tanah meningkat sehingga dapat diindikasikan bahwa perlakuan $\mathrm{E}$ adalah dosis yang terbaik diantara semua perlakuan jika dilihat dari hasil uji kualitas kimia dan fisik tanah. Menurut Wydiantara dkk (2015), adanya perbedaan nilai KTK dikarenaka adanya perbedaan pada jumlah kandungan bahan organik dalam tanah, selain itu juga dipenaguri oleh kandungan fraksi liat yang tinggi karena tingginya fraksi liat maka stabilitas agregat tanah juga tinggi karna adanya ikatan dalam partikel tanah.

\subsection{Hasil Uji Parameter tekstur pasir, debu dan liat Sebelum dan Sesudah perlakuan}

Tekstur menunjukan sifat halus atau kasar butiran tanah antara debu (slit), liat (clay) dan pasir (sand) yang terkandung di dalam tanah yang dimanfaatkan sebagai dimensi partikel dan perbandingan relatif golongan tanah. Hasil Uji Parameter tekstur pasir dapat dilihat pada Tabel 10.

Tabel 10. Hasil Uji Parameter Pasir

\begin{tabular}{cccc}
\hline \hline $\begin{array}{c}\text { Parameter tekstur } \\
\text { pasir }\end{array}$ & Kode Sampel & Sebelum & Sesudah \\
\cline { 2 - 4 } & A & 47,51 & 49,99 \\
B & 14,34 & 20,21 \\
C & 14,94 & 17,00 \\
D & 14,95 & 15,56 \\
E & 17,55 & 16,86 \\
\hline
\end{tabular}

Sumber: Hasil Analisis Laboratorium Fakultas Pertanian UNTAN 2020

Terjadi peningkatan kadar pasir pada variasi media tanam setelah dilakukan penanaman sengon dengan kode A hingga D dan penurunan nilai fraksi pasir pada kode tanam E, peningkatan kadar fraksi pasir tertinggi yaitu pada perlakuan B dimana Sengon ditanami di tanah pascatambang tanpa perlakuan apapun. Menurut Hakim et al. (1986) dalam Soniari (2016) Nilai KTK yang rendah dikarenakan dominasi fraksi pasir sehingga luas permukaan jenis dalam kation juga rendah. Kohnke (1989) juga menyatakan bahwa, tanah bertekstur kasar (pasir) mempunyai kandungan bahan adsorbs dan kapasitas menahan air sangat rendah.
Untuk hasil uji parameter tekstur debu dapat dilihat Tabel 11.

Tabel 11. Hasil Uji Parameter Debu

\begin{tabular}{lccc}
\hline \hline $\begin{array}{c}\text { Parameter tekstur } \\
\text { debu }\end{array}$ & Kode Sampel & Sebelum & Sesudah \\
\cline { 2 - 4 } & $\mathrm{A}$ & 30,53 & 29,80 \\
$\mathrm{~B}$ & 49,82 & 47,24 \\
$\mathrm{C}$ & 49 & 50,04 \\
$\mathrm{D}$ & 49,93 & 51,21 \\
$\mathrm{E}$ & 47,58 & 46,14
\end{tabular}

Sumber: Hasil Analisis Laboratorium Fakultas Pertanian UNTAN 2020

peningkatan kadar fraksi debu setelah dilakukan penanaman sengon terjadi pada perlakuan dan $D$ sedangkan pada perlakuan A, B dan E terjadi penurunan kadar fraksi debu. Peningkatan dan penurunan yang terjadi tidak signifikan. Foth (1998) dalam Soniari (2016) terdapat ikatan negatif yang buruk antara fraksi pasir dan debu karena rendahnya permukaan spesifiknya sehingga berpengaruh pada nilai Kapastis Tukar Kation (KTK) yang juga rendah. Untuk hasil uji parameter tekstur liat dapat dilihat Tabel 12.

Tabel 12. Hasil Uji Parameter Liat

\begin{tabular}{lccc}
\hline \hline & Kode Sampel & Sebelum & Sesudah \\
\cline { 2 - 4 } & A & 21,96 & 20,21 \\
Parameter & B & 35,84 & 32,55 \\
tekstur liat & C & 36,06 & 32,96 \\
& D & 35,12 & 33,23 \\
& E & 34,87 & 33,66 \\
\hline
\end{tabular}

Sumber: Hasil Analisis Laboratorium Fakultas Pertanian UNTAN 2020

Ada perubahan komposisi ketiga fraksi tanah sebelum dan sesudah perlakuan, terjadi penurunan kadar liat pada semua perlakuan setelah dilakukan penanaman Sengon. Tekstur yang memiliki daya menahan air yang baik adalah fraksi liat yang jika dibandingkan dengan fraksi pasir dan debu memiliki kerentanan yang tinggi terhadap longsor. Terjadinya penurunan kadar fraksi liat setelah adanya vegetasi hal ini tidak sesuai dengan pernyataan Hakim et al. (1986) dalam Soniari (2016) yang menyatakan bahwa tanah dengan kandungan liat yang tinggi memilik kecendrungan kandungan kadar air, bahan organik, dan KTK yang juga tinggi.

\subsection{Pengaruh Perlakuan Media Tanam Terhadap Sifat Fisik dan Kimia Tanah Serta Pertumbuhan Tanaman}

Variasi media tanam berpengaruh terhadap kualitas fisik dan kimia tanah serta pertumbuhan tanaman. Berdasarkan hasil analisis uji kualitas kimia dan fisik tanah, variasi media tanam E (60\% cocopeat $+25 \%$ arang sekam $+15 \%$ kotoran ayam) memiliki 
peningkatan parameter $\mathrm{pH}, \mathrm{KTK}, \mathrm{C}$-organik, N- total, P2O5 serta kadar debu, liat, dan pasir yang paling baik setelah dilakukan penanaman sengon. Setelah 1 bulan penanaman, kadar parameter C- Organik, Nitrogen Total dan KTK pada lahan dengan topsoil (perlakuan A) memiliki nilai yang lebih baik jika dibandingkan dengan variasi media tanam E (60\% cocopeat $+25 \%$ arang sekam $+15 \%$ kotoran ayam) yang memiliki kadar yang lebih rendah, namun untuk kadar parameter $\mathrm{pH}$ dan $\mathrm{P}_{2} \mathrm{O}_{5}$ variasi media tanam E memiliki nilai yang lebih baik daripada penanaman di lahan yang masih tersedia topsoil.

Pertumbuhan tanaman terbaik terletak pada variasi perlakuan $\mathrm{D}(50 \%$ cocopeat $+25 \%$ arang sekam $+25 \%$ kotoran ayam, dengan rata-rata pertambahan tinggi sebesar $13,7 \mathrm{~cm}$ dan pertambahan rata rata jumlah daun sebesar 6 helai setelah 1 bulan penanaman. Adanya kombinasi antara dosis cocopeat, arang sekam dan kotoran ayam pada perlakuan D berpengaruh nyata terhadap pertumbuhan tinggi tanaman serta penambahan jumlah daun tanaman sengon. Menurut Sunarya dan Arasyid (2019) kondisi fisik, kimia maupun biologi tanah pascatambang dapat diperbaiki dengan adanya bahan organik yang membantu bibit sengon menjadi lebih tinggi. Kondisi fisik media tanam menjadi lebih porous dan tata udara tanah diduga karena adanya penambahan arang sekam padi kedalam campuran media tanam sehingga proses respirasi tanah menjadi baik sehingga akan tersedia energi lebih banyak untuk perkembangan dan pertumbuhan bibit. (Dharmawan dan Siregar, 2014).

\section{Kesimpulan}

Cocopeat adalah media tanam yang dibuat dari sabut kelapa sebagai pengganti tanah. Kandungan parameter $\mathrm{pH}, \% \mathrm{C}$ - organik, KTK, dan $\mathrm{N}$ total dalam media tanam cocopeat memiliki kandungan yang lebih baik jika dibandingkan topsoil dan tanah pascatambang, terkecuali untuk parameter $\mathrm{P}_{2} \mathrm{O}_{5}$, kadar debu, liat, dan pasir, maka topsoil memiliki kandungan yang lebih baik. Kandungan parameter fisik dan kimia terendah terdapat pada tanah pascatambang. Komposisi media tanam kombinasi cocopeat, arang sekam, dan kotoran ayam memiliki pengaruh yang baik terhadap pertumbuhan tanaman Sengon karena memiliki unsur hara yang lebih tinggi dibandingkan dengan sengon yang ditanam pada lahan dengan topsoil, tanpa topsoil atau hanya dengan cocopeat saja. Dosis variasi paling optimal dalam pertumbuhan Sengon dari segi pertumbuhan fisik tanaman (pertumbuhan tinggi dan pertambahan cabang daun) yaitu pada variasi kode tanam D (50\% cocopeat, 25\% arang sekam dan 25\% kotoran ayam) dengan pertambahan tinggi tanaman rata-rata $13,7 \mathrm{~cm}$ dan cabang daun sebanyak 6 helai yang lebih signifikan dibandingkan perlakuan media tanam lainnya.

\section{DAFTAR PUSTAKA}

Agustin, L. 2010. Pemanfaatan Kompos Sabut Kelapa dan Zeolit sebagai Campuran Tanah untuk Media Pertumbuhan Bibit Kakao pada Beberapa Tingkat Ketersediaan Air. Skripsi Fakultas Pertanian, Universitas Jember, Jember, Indonesia.

Bahar, A., Indrayatie, E.R., Pujawati, E. D. 2020. Pengaruh Serai Wangi (Cymbopogon Nardus) Terhadap Sifat Fisik dan Kimia Tanah. Jurnal Sylva Scienteae Vol. 03 No. 1.ISSN 2622-8963 (media online)

Cahyo,A., Sahuri., Iman N., Ardika, R. 2019. Cocopeat as Soil Substitute Media for Rubber (Heveabrasiliensis Müll. Arg.) Planting Material. Journal of Tropical Crop Science Vol. 6 No. 1.

Fitriani, D. 2016. Pertumbuhan Tanaman Sengon (Paraserianthes falcataria L.) Bermikroza Pada Lahan Tercemar PB. Jurusan Biologi Fakultas Matematika dan Ilmu Pengetahuan Alam Institut Teknologi Sepuluh Nopember: Surabaya

G, Subowo. 2011. Penambangan Sistem Terbuka Ramah Lingkungan dan Upaya Reklamasi Pascatambang untuk Memperbaiki Kualitas Sumberdaya Lahan dan Hayati Tanah. Jurnal Sumberdaya Lahan Vol. 5 No. 2.

Gunawan.,Wijayanto, Nurheni., Budi,S. 2019. Karakteristik Sifat Kimia Tanah dan Status Kesuburan Tanah Pada Agroforesti Tanaman Sayuran Berbasis Eucalyptus Sp. Jurnal Silvikultur Tropika Vol. 10 No. 02 ISSN: 20868227.

Hasibuan, A. 2015. Pemanfaatan Bahan Organik dalam Perbaikan Beberapa Sifat Tanah Pasir Pantai Selatan Kulon Progo. Planta Tropika Journal of Agro Science Vol 3 No 1.

Hasriani, D.K. Kalsim, dan A. Sukendro. 2013. Kajian Serbuk Sabut Kelapa (Cocopeat) Sebagai Media Tanam (Study Of Cocopeat As Planting Media). IPB Press, Bogor. Indonesia. Bogor: IPB.

Hirfan. 2016. Strategi Reklamasi Lahan Pasca Tambang. PENA TEKNIK: Jurnal Ilmiah Ilmu-Ilmu Teknik Volume 1, Nomor 1: 101 - 108.

Irawan, A. dan Hidayah, H. N. 2014. Kesesuaian Penggunaan Cocopeat sebagai Media Sapih Pada Politube dalam Pembibitan Cempaka (Magnolia elegans). Jurnal Wasian 1(2):73-76.

Irawan. A dan Y. Kafiar. 2015. Pemanfaatan Cocopeat dan Arang Sekam Padi Sebagai Media Tanam Bibit Cempaka Wasian (Elmerrilia ovalis). Balai Penelitian Kehutanan (BPK) Manado. ISSN 2407-8050.

Irwan, A. W. 2017. Pengaruh jarak tanam berbeda dan berbagai dosis pupuk kandang ayam terhadap pertumbuhan dan hasil tanaman hanjeli pulut (Coix lacryma-jobi L.) di dataran tinggi Punclut. Jurnal Kultivasi Vol. 16(1) Maret.

Margareta,Maria.2017. Pengaruh Kombinasi Tanah, Arang Sekam ,Kapur dan Pupuk Kompos Sebagai Media Tanam Terhadap Pertumbuhab Tanaman Ciplukan (Physalis angulata L.) dalam Polybag. Skripsi. Univesitas Sanata Dharma. Yogyakarta.

Muliawan, L. 2009. Pengaruh Media Semai Terhadap Pertumbuhan Pelita (Eucalyptus pellita F. Muell). Institut Pertanian Bogor. Bogor. $104 \mathrm{hlm}$.

Munir, M. 2017. Kajian Reklamasi Lahan Pascatambang Di Jambi, Bangka, Dan Kalimantan Selatan Jurnal clorofil. Vol. 1 No. 1,: 11-16. ISSN 2598-6015.

Mustafa, M, Ahmad, I., Ansar, Muh.,Syafiuddin, M. 2012. Dasar- Dasar Ilmu Tanah. Program Studi Agroteknologi 
Jurusan Ilmu Tanah Fakultas Pertanian Universitas Hasanuddin:Makassar.

Muswita., Murni, P., Herliana, L., 2008. Pengaruh Pupuk Organik Terhadap Pertumbuhan Sengon (Albizia falcataria (L.) Fosberg). Vol 1 No 1.

Nagur, Y. 2017. Kajian Hubungan Bahan Organik Tanah Terhadap Produktivitas Lahan Tanaman Padi di Desa Kebon Agung. Skripsi Program Studi Agroekoteknologi. Universitas Pembangunan Nasional "Veteran" Yogyakarta

Puspita, N. 2015. Analisis Kemasaman Tanah dan C-Organik Tanah Bervegetasi Alang- Alang Akibat Pemberian Pupuk Kandang Ayam dan Pupuk Kandang Kambing. Media Sains, Volume 8 Nomor 2. ISSN ELEKTRONIK 2355-9136.

Putri, A. Setiadi Y., Istomo., 2013. Evaluasi Keberhasilan Tanaman Hasil Revegetasi Di Lahan Pasca Tambang Batubara Site Lati PT. Berau Coal Kalimantan Timur. JURNAL SILVIKULTUR TROPIKA Vol. 04 No. 02 ISSN: 2086-8227

Rachman, A. Sutono, Irawan, dan Suwastka W. 2017. Indikator Kualitas Tanah pada Lahan Bekas Penambangan. Jurnal Pertambangan. ISSN 1907-0799

Ramadhan,D., Riniarti,M dan Santoso,T. 2018. Pemanfaatan Cocopeat sebagai Media Tumbuh Sengon Laut (Paraserianthes falcataria)dan Merbau Darat (Intsia palembanica). Jurnal Sylva Lestari. Vol. 6 No. 2. ISSN (online) 2549-5747

Ramadhana, Dwi, D., Donantho,D., dan Rachel,R. 2019. Penilaian Status Kesuburan Tanah pada Lahan Pascatambang di Areal PT. Trubaindo Coal Mining Kabupaten Kutai Barat. Jurnal Agroekoteknologi Tropika Lembab. Volume 2, Nomor 1, Agustus 2019. ISSN: 2622-3570.

Ramadhani. R.S., dan Wulandari. R.S. 2018. Pengaruh Proporsi Campuran Media Sapih Pada Pertumbuhan Bibit Mahoni (Swietenia mahagoni) di Persemaian. Jurnal Hutan Lestari. Vol. 6 (4) : 1009 - 1019.

Saidy A.R. 2018. Bahan Organik Tanah: Klasifikasi, Fungsi, dan Metode Studi. Lambung Mangkurat University Press: Banjarmasin.

Saptiningsih, E., dan Haryanti, S. 2015. Kandungan Selulosa dan Lignin Berbagai Sumber Bahan Organik Setelah Dekomposisi pada Tanah Latosol. Buletin Anatomi dan Fisiologi Volume XXIII, Nomor 2.

Saputra, Indra, S., Nelvia., Andri, Siziko.,2016. Pemberian Kompos TKKS dan Cocopeat pada Tanah Subsoil Ultisol
Terhadap Pertumbuhan Bibit Kelapa Sawit (Elaeis guineensis Jacq.) di Pre- Nursery. Jurnal Agroteknologi, Vol. 7 No. 1.

Saputra,E., Subiantoro, R., Gusta, Adreyadhe, R. 2019. Pengaruh Kombinasi Media Lapisan Tanah dan Takaran Cocopeat pada Pertumbuhan Bibit Kakao (Theobroma cacao L.). Jurnal AIP Volume 7 No. 1.

Sembiring S. dan Simon. 2008. Sifat kimia dan fisik tanah pada areal bekas tambang bauksit. Info Hutan. 5(2):123134.

Siti Hani. 2013. Manual Budidaya Sengon. Bogor. Badan Penelitian Dan Pengembangan Kehutanan Pusat Penelitian Pengembangan Peningkatan Produktivitas Hutan.

Sittadewi, Hanggari. 2016. Mitigasi Lahan Terdegradasi Akibat Penambangan Melalui Revegetasi. Jurnal Sains dan Teknologi Mitigasi Bencana, Vol. 11, No. 2.

Soniari, Ir 2016. Korelasi Fraksi Partikel Tanah dengan Kadar Air Tanah, Erodibilitas Tanah dan Kapasitas Tukar Kation Tanah Pada Beberapa Contoh Tanah di Bali. Program Studi Agroekoteknologi Universitas Udayana. Bali

Suganda, A., A. Rachman, dan Sutono. 2002. Petunjuk Pengambilan Contoh Tanah. Balittanah, Litbang, Departemen Pertanian. Bogor.

Sunarya Y dan Arasyid F. 2019. Pertumbuhan Sengon (Albizzia falcataria L.) Pada Media Tanam Campuran Tailing, Tanah dan Bahan Organik. Media Pertanian Vol. 4 No. 1, Mei 2019, pp. 8-12 ISSN : 2085-4226.

Supriyanto dan Fiona, F. 2010. Pemanfaatan Arang Sekam untuk Memperbaiki Pertumbuhan Semai Jabon (Anthocephalus cadamba (Roxb.) Miq) pada Media Subsoil. JURNAL SILVIKULTUR TROPIKA Vol. 01 No. 01 ISSN: 2086-8227.

Suryani,Ida. 2014. Kapasitas Tukar Kation (KTK) Berbagai Kedalaman Tanah Pada Areal Konversi Lahan Hutan. Jurnal Agrisistem. Vol. 10 No.2 ISSN 1858-4330.

Widowati. 2004. Pengaruh Kompos Pupuk Organik Yang Diperkaya Dengan Bahan Mineral dan Pupuk Hayati Terhadap Sifat-Sifat Tanah, Serapan Hara dan Produksi Sayuran Organik. Laporan Proyek Program Pengembangan Agribisnis. Balai Penelitian Tanah.

Taqiyuddin, Muhammad., Hidayat,L,. 2020. E Reklamasi Tanaman Adaptif Lahan Tambang Batubara PT. BMB Blok Dua Kabupaten Tapin Kalimantan Selatan. Volume 45 Nomor 3. e-ISSN 2355-3545. 